\title{
At least you tried: The value of De Dicto concern to do the right thing
}

\section{Claire Field ${ }^{1} \mathbb{D}$}

Accepted: 11 January 2022 / Published online: 5 March 2022

(c) The Author(s) 2022

\begin{abstract}
I argue that there are some situations in which it is praiseworthy to be motivated only by moral rightness de dicto, even if this results in wrongdoing. I consider a set of cases that are challenging for views that dispute this, prioritising concern for what is morally important (de re, and not de dicto) in moral evaluation (for example, Arpaly, 2003; Arpaly \& Schroeder, 2013; Harman 2015; Weatherson, 2019). In these cases, the agent is not concerned about what is morally important (de re), does the wrong thing, but nevertheless seems praiseworthy rather than blameworthy. I argue that the views under discussion cannot accommodate this, and should be amended to recognise that it is often praiseworthy to be motivated to do what is right (de dicto).
\end{abstract}

Keywords Praiseworthiness $\cdot$ Blameworthiness $\cdot$ Neuroatypicality $\cdot$ Moral responsibility $\cdot$ Moral recklessness $\cdot$ Moral Risk

It is possible to be better or worse at moral deliberation, and many of us have reason to think we are worse rather than better. Fortunately, we can ask for help. The view I defend here says that asking for advice about what is morally right, particularly when you know you need it, is praiseworthy rather than blameworthy. This point ought to be uncontroversial. However, it is ruled out by a group of views, De Re Concern views, that prioritise concern for what is morally important (de re) in moral evaluation (Arpaly, 2003; Arpaly \& Schroeder, 2013; Harman 2015; Weatherson, 2019). These views say that there is nothing praiseworthy about aiming to do the morally right thing, and it is always blameworthy to fail to care about the things that are morally important. Zoe Johnson King (2019) has recently challenged this on the grounds

Claire Field

c.a.field1@stir.ac.uk

1 Varieties of Risk, University of Stirling, Stirling, Scotland, UK 
that when the agent acts rightly, motivation de dicto is just as good as motivation de re. Here, I argue that motivation de dicto is sometimes also just as good when the agent acts wrongly. Specifically, I focus on cases where the agent faces psychological or epistemic barriers to caring about the right things. I argue that De Re Concern views are forced to say the wrong thing about these cases.

Section 1 introduces the cases at issue. Section 2 clarifies the sense in which concern for moral rightness de dicto is praiseworthy. Section 3 outlines De Re Concern views and shows how the cases are a problem for them. Section 4 discusses some ways that these views might attempt to accommodate these cases, and Sect. 5 presents my view of how these views should be amended to deal with the cases - the Inclusive View. The Inclusive View says that the set of morally important things should be expanded to include moral rightness itself.

\section{Bad advice cases}

To set the scene, consider a non-moral example.

Pasta. I am a bad cook. One manifestation of my culinary ineptitude is a general failure to notice or appreciate the difference made by adding salt to the water while cooking pasta. Fortunately, I know that I am a bad cook, so I can take steps to compensate for this. I know when I am out of my depth, and I follow a recipe book when I am making dinner for other people. Unfortunately, my recipe book contains a number of misprints, so I often still get it wrong.

Whatever is of first-order culinary importance when cooking pasta, I lack sufficient concern for it. This is unfortunate; it makes me a bad cook. However, because I know that I am a bad cook I can take steps to compensate. I am a bad cook, but not a reckless cook. When I recognise that I am out of my depth I defer to experts (i.e. the recipe book), particularly when it is important to get things right (e.g. when I am making dinner for other people). I thus avoid culinary recklessness. While this is a good method, it is not infallible-sometimes recipe books contain misprints. Nevertheless, my motivation to determine the culinarily correct thing (de dicto), and thus avoid culinary disaster, is to be praised. Here is another example.

Ambassador. In Ursula Le Guin's novel The Left Hand of Darkness (1969), the central character, $\mathrm{Ai}$, is an ambassador to an alien world. There, the people value 'shifgrethor' very highly. As Le Guin tells it, shifgrethor is untranslatable, though it has a moral flavour, and seems related to respect, social status, and pride. Although the ambassador tries very hard to understand shifgrethor, after years of studying the culture he still finds it confusing and frequently makes blunders. He is not sure whether shifgrethor accurately captures moral truth. It seems equally plausible both that shifgrethor is morally irrelevant, and that the alien culture has discovered a genuine aspect of moral truth unknown to his own culture. Ai wants to do whatever the right thing is, so he scrupulously 
avoids actions that he knows are violations of shifgrethor (provided they do not conflict with other moral prohibitions he recognises). ${ }^{1}$

Let us suppose that, in fact, shifgrethor does capture something true about morality. This would mean that in not fully appreciating shifgrethor, Ai does not fully appreciate some of the important first-order features of the moral landscape. Nevertheless, he is motivated to do the right thing, whatever that is. Like my culinary motivations, Ai's motivation to do the right thing (de dicto)seems praiseworthy, even if he misunderstands the advice and ends up doing something wrong. Provided that Ai identifies a sufficiently wise moral advisor, relying on advice reduces the risk of doing something morally wrong. However, like recipe books, even wise advisors are not infallible, and Ai may still end up getting it wrong.

The view I defend here accommodates this. It says that good faith attempts to avoid recklessness are praiseworthy, and not blameworthy, and this is true regardless of whether the agent does the right thing, and regardless of the details of their firstorder concerns. This generates a disagreement with De Re Concern views: on my view, agents are sometimes out of touch with what is in fact morally important, not to blame for being out of touch, and are praiseworthy for being motivated to avoid doing the wrong thing. In such situations, the agents are praiseworthy, rather than blameworthy, despite not being motivated only by moral rightness (de dicto) and not by what is morally important (de re). De Re Concern views disagree - according to them, this is not possible because praiseworthiness requires concern for what is morally important de re. Lack of concern for what is morally important de re implies blameworthiness.

This state of being blamelessly out-of-touch with what is morally important could come about in various ways. For example: through one's social position ${ }^{2}$, implicit biases $^{3}$, a defective affective system ${ }^{4}$ (due to amygdala damage ${ }^{5}$, dementia ${ }^{6}$, depres-

\footnotetext{
${ }^{1}$ Such situations are not only the stuff of science fiction. Travel and intercultural exchange can generate situations similar to Ai's. That is, provided it is possible for different cultures to use moral terms that are accurate descriptions of moral truth within that context, but not perfectly translatable between cultures. Fortunately, there are ways for travellers to anticipate such situations, and employ strategies to avoid these blunders: they can do research in advance, or employ a guide.

2 According to standpoint epistemologists, an agent's social position can provide unique access to information, concepts, or ways of interpreting information (see Toole, 2019). See Calhoun (1989) for example of how this could put one out-of-touch with what is morally important).

3 (Zheng, 2016; Anderson, 2015; Holroyd, 2012; Kahneman et al., 1982).

${ }^{4}$ Many think that the affective system plays an important role in helping us form moral judgments quickly and efficiently (Buss, 2014; Prinz, 2006; Railton, 2014; Sinhababu, 2017; Kauppinen, 2014).

${ }^{5}$ For some evidence of the connection between the amygdala and moral judgment, see (Blair, 2007; Murray, 2007; Blair et al., 2005; Kauppinen, 2014).

${ }^{6}$ See (Nelkin, 2019).
} 
$\operatorname{sion}^{7}$, distractingly strong emotions ${ }^{8}$, over-reliance on empathy ${ }^{9}$, or trauma ${ }^{10}$ ). For illustration, I focus on how some neuroatypical ways of thinking could have this effect. While they are not the only source of examples, neuroatypical traits are particularly interesting because although they are often viewed as limitations, they are also robust features of a person's character. Not only are they difficult to change, but it is not clear that it would be morally acceptable to expect people to change them. If these traits represent genuine differences in thinking styles, then we seem to have a moral duty to accommodate them somehow. This accommodation would seem to require (at least) two things: first, charitable interpretations of neuroatypical perspectives - we should not misinterpret non-blameworthy behaviour as blameworthy behaviour and second, avoiding commitment to criteria of blameworthiness that make it unreasonably difficult for neuroatypical people to avoid blame. Similar accommodations of difference in thinking styles are familiar in other areas. In education it is a standard assumption that children should be allowed to do well in school regardless of whether they are a visual, auditory, or kinaesthetic learner. To help ensure that children do not fail to do well merely because of these different thinking styles, teachers often plan lessons aimed at various different thinking styles. ${ }^{11}$ Similarly, I suggest here that people should not fail to do well in morality, and be found blameworthy, merely because they think differently.

Characteristically, autistic individuals often struggle to understand the neurotypical social world ${ }^{12}$, particularly in relation to social communication, social referencing and attention. This can lead to difficulties predicting how behaviour will affect others (see Baron-Cohen, 1999), and it can make them more likely to be interpreted by others as blunt, rude, or unkind. This can have implications for moral evaluation when social interactions carry moral significance. Assuming this is correct, autism involves robust and identifiable psychological traits that can easily cause moral blunders. To illustrate, here is an example:

Imagination. Jane is autistic. While she has learned to identify some of the more obvious aspects of the emotional and social spheres, she finds it difficult to understand many aspects of other people's (particularly neurotypical

\footnotetext{
7 See (Terroni \& Fraguas, 2010; Bell, 2018).

${ }^{8}$ For example, strong feelings such as anger, love, and pride can sometimes prevent us from paying attention to morally important things that we would view as significant in a cooler hour of reflection (Enoch, 2014).

${ }^{9}$ For example, some psychologists have thought that empathy can sometimes lead us to overlook moral claims of those who are different (Bloom, 2016).

${ }^{10}$ For example, from armed conflict (see Molendijk et al., 2018; Kinghorn, 2012; Hurley, 2010).

11 For evidence of the prevalence of the accommodation of different learning styles in education and educational theory, see (Pashler et al., 2009; Silver et al., 2000; Coffield et al., 2004; Dunn et al., 2002).

12 There are various competing views of what exactly causes characteristic autistic traits. I do not intend to wade into this here. Perhaps the most popular explanation is that autistic individuals lack a 'theory of mind' - the ability to attribute mental states to themselves and others (Barnbaum, 2008; Baron-Cohen et al., 1985). Others have characterised autism as: a processing bias causing intense focus on details at the expense of the overall picture of how the details fit together (Frith \& Happé, 1994; Frith, 1991), a deficiency in the ability to think counterfactually (Stout, 2016), and oversensitivity to sensory information (Grandin \& Panek, 2013).
} 
people's) emotional lives. This difficulty presents itself in failures to interpret and predict others' feelings, as well as a degree of scepticism about the moral significance of some of the hurt feelings that others report. For example, Jane struggles with the ethics of asserting hurtful truths. She knows that some assertions can be upsetting, but she struggles to identify which these are. Explanations of why some personal truths can be upsetting strike her confusing and a little far-fetched. While she tries to be charitable, she struggles to believe that it could really be morally important to avoid such assertions, particularly when this comes at the expense of saying things that are relevant and true. Nevertheless, Jane wants to do the right thing, whatever that is. Aware of the ways in which she struggles with interpersonal interactions with neurotypical people, when she notices that there is a risk of hurting others' feelings in a way that could be wrong, Jane asks a friend for advice, and does whatever she says is the right thing to do.

Jane's psychology puts her out of touch with some of the features of the social world, particularly in novel situations involving interpersonal interactions with neurotypical people. In so far as these features are part of what is morally important (de re), she does not manifest appropriate concern for them. Her lack of understanding of them prevents her from caring appropriately about them. Jane is sceptical of the importance of avoiding asserting hurtful truths, just as I am sceptical of the importance of adding salt to pasta. This scepticism means that although she tries to avoid wrongdoing, it is not quite true to say that she cares about the right things (what is morally important de re). However, she knows that she is prone to making mistakes in this domain, and this knowledge enables her to mitigate the risk of doing something wrong. That said, her strategy is not infallible. Even the best advisors can be mistaken. When they are, trusting them will lead to doing the wrong thing. Nevertheless, even when it leads to wrongdoing, the motivation to avoid wrongdoing is praiseworthy - even in absence of appropriate concerns for the things of first-order moral importance.

\section{Praiseworthy motivations?}

The argument I am building against De Re Concern views relies on the claim that attempts to avoid doing the wrong thing are, in general, praiseworthy. Specifically, they are praiseworthy even when they are motivated solely by moral rightness $d e$ dicto, and none of the morally important things de re. Note that this need not be maximal praiseworthiness. ${ }^{13}$ In this section, I give some reasons to think this is true.

\footnotetext{
${ }^{13}$ For example, we might think moral deference can never be maximally praiseworthy. Perhaps it implies that the agent lacks the moral understanding necessary for virtue (Hills, 2009), undermines moral worth (Fletcher, 2016), outsources our moral agency (Hopkins, 2007; Nickel, 2001), prevents authentic interaction (Skarsaune, 2016), or is simply likely to be unsuccessful because there are no moral experts (McGrath, 2009; Williams, 1995). We nevertheless might wonder whether it is always reasonable to expect agents to put in the extra effort needed to achieve these aspects of maximal moral praiseworthiness, or whether achieving these is supererogatory.
} 
First, in attempting to avoid the risk of wrongdoing one avoids recklessness about whether one's actions are wrong. Recklessness is prima facie blameworthy. For instance, in many legal systems recklessness is the mens rea of various crimes. Moral recklessness is recklessness as to whether one's actions are morally wrong. If one is uncertain about whether one's actions are morally permissible, there is a risk of doing something wrong. Since we know that we are fallible, and so cannot always be sure that our assessment of what is morally right is correct, there is always some moral risk. Not all of these moral risks are reckless ${ }^{14}$ - this depends on their size, and their justification. Nevertheless, if one has no justification for taking a risk of doing something wrong, this is plausibly reckless. In general, we should avoid taking unjustified risks. To fail to care at all about whether one is correct in one's first-order judgments is to be (morally) reckless as to whether one's actions are. For illustration, consider the following example:

Dinner. Martha is deciding whether to have steak or tofu for dinner. She prefers steak but knows there are ethical questions around meat-eating. She has studied the relevant biological and philosophical literature and concluded that it is not wrong to eat steak. But she is not completely certain of this; as with any other philosophical conclusion, she has doubts. As a matter of fact, Martha is right in the sense that a fully informed person in her position would know that in this instance it is permissible for her to order steak for dinner, but Martha cannot be certain of this.

There are various justifications that Martha might give for choosing steak. Perhaps the fact that steak tastes nice is sufficient. Or, perhaps one steak at one dinner would make so little difference that if it is wrong, it is only be a tiny wrongdoing, and so requires very little justification. ${ }^{15}$ The relevant point is that she needs some justification for taking the risk; if she has none at all, then choosing steak is reckless.

If Martha opts for tofu out of a motivation to avoid doing the wrong thing this can only plausibly be motivated by moral rightness de dicto, since she is uncertain about what is morally right de re. Proponents of De Re Concern views have tended to agree on this point (see Harman 2015, Weatherson 2014). The agents in the Bad Advice Cases are in a comparable position to Martha. They know that if they do not defer to their advisors, they are highly likely to do something wrong - although they are in the dark about what that is. In using what they know about their limitations to mitigate the risk of possible wrongdoing, these agents are plausibly doing precisely what is morally required. Since, like Martha, they are out of touch with what is morally right de re, they too can only do this out of a motivation for moral rightness de dicto. ${ }^{16}$

\footnotetext{
${ }^{14}$ We are often uncertain about the moral valence of our actions, so in acting we take a small risk that what we do is wrong. If these small risks were always blameworthy, we would almost always be blameworthy (see Harman 2015; Weatherson, 2014).

15 See Kagan (2011).

${ }^{16}$ I say that the agents are in a comparable situation to Martha. They are not in precisely the same situation. Unlike Martha, they do not have a clear morally safe option (the moral equivalent of choosing tofu), because they are unsure about what is morally. Nevertheless, they have an option that (from their perspective) has a much better chance of being morally right, because it is supported by a trusted moral advisor
} 
Caring about what is morally right de dicto is thus a way of caring about avoiding recklessness. That this de dicto motivation is a praiseworthy motivation is the key point that the argument against De Re Concern views (and in favour of the Inclusive View) rests on.

Second, as Johnson King (2019) argues, motivations to act rightly (de dicto) are very often crucial components in the psychology of agents who we think of as moral saints - that is, agents who consistently perform morally right acts, and whose lives are guided by a commitment to act rightly. Johnson King points out that moral saints are like this, very often, because they are motivated by moral rightness de dicto. Neither their "consistently right acts nor [their] perfectly accurate moral beliefs are a fluke. [They are] this way because [they are] motivated by rightness de dicto". As she notes, it would strange to think that the usual motivations of people we consider moral saints are not praiseworthy to any degree whatsoever $(2019,417)$.

Third, as Johnson-King (2019) also argues, if we keep everything else fixed it is difficult to find any difference in praiseworthiness between agents who are motivated by what is morally right $d e r e$, and agents who are motivated by moral rightness de dicto. If we hold fixed what the agent does, whether she is successful, and whether her beliefs are true, these agents seem equally praiseworthy (or not). This should remove the temptation to worry that concern for moral rightness de dicto cannot be praiseworthy because it is shared by other, non-praiseworthy agents. There are many infamous examples of people committing atrocities in the name of doing what is morally right, while being deeply mistaken about what is morally right - ancient Hittite slave-traders ${ }^{17}$, Nazis ${ }^{18}$, and others. While the motivation to do the right thing is praiseworthy in all cases, when the agent is deeply mistaken about what is right this praiseworthiness can be outweighed by blameworthiness deserved for committing horrible atrocities. However, there are important differences between agents in the Bad Advice Cases (who are overall praiseworthy) and Hittite slave-traders, Nazis, and similar agents (who are overall blameworthy).

For example, three things are true of Jane that are not obviously true of these other deeply mistaken agents. First, Jane's psychology means that she faces an epistemic barrier to understanding and appreciating the first order moral considerations of her situation. Second, Jane recognises her own fallibility and uses this to manage the moral risk of the situation. Third, the wrong Jane commits is relatively minor. It is not clear that these things are true for the more familiar examples of deeply mistaken agents who commit atrocities. While it might be contended that being in the grip of a false moral view is an epistemic barrier to appreciating the first order considerations of one's situation, it is not clear that this is on a par with the psychological limitations Jane faces. For example, it is not clear that holding a false moral view makes one unable to appreciate the truth. Nevertheless, perhaps someone who commits atrocities having sought advice in good faith is more praiseworthy, or at least less blame-

with a good track record - it is the less risky option. My claim here is that if we thought that Martha was praiseworthy for avoiding moral risk and choosing tofu, we should also think that the agents in Bad Advice Cases are praiseworthy for choosing the option that is less risky.

17 See Rosen (2002, 65), Slote (1982).

18 See Arpaly (2003, 92-93). 
worthy, than someone who does not even bother to seek advice. If this is right, then a natural explanation of this is that it is praiseworthy to be motivated to avoid risks of wrongdoing, even if you end up getting it wrong. Of course, the praiseworthiness of this attempt to avoid moral risk would be comparatively small, and unlikely to outweigh the blame deserved if the atrocity were very severe.

Some have disagreed. Those who defend De Re Concern views have thought that attempts to avoid doing the wrong thing are not praiseworthy, because praiseworthiness requires (only) that the agent is motivated by what is morally important (de re). Additionally, they have thought that it is in no way praiseworthy to act out of concern to do the right thing (de dicto). Rather, in so far as the agent lacks the correct firstorder concerns, they are blameworthy. Moreover, De Re Concern views hold that there is nothing good to say about attempting to do the right thing, when one lacks the correct first-order concerns. So, attempts to do the right thing are neither praiseworthy, nor can they mitigate any blame deserved. The following section discusses these views in further detail.

\section{De Re Concern views}

De Re Concern views say that moral evaluation should prioritise concern for what is in fact morally important - that is, whatever it is that makes particular actions right or wrong. For example, that it causes distress is, perhaps, what makes asserting hurtful truths morally wrong. According to De Re Concern views, agents who act out of concern for morally important things (such as distress caused) are praiseworthy, and those who behave with a lack of concern for these things are blameworthy. Furthermore, it is in no way praiseworthy to act out of a concern to do the morally right thing de dicto, so a concern to do the morally right thing de dicto cannot mitigate any blame otherwise deserved. ${ }^{19}$ Praiseworthy agents should act out of concern for what is morally important de re (fairness, happiness, kindness, and so on), and nothing else. Crucially, moral rightness itself is not counted among what is morally important ( $d e$ re). ${ }^{20}$ We can interpret De Re Concern views as committed to the following claims:

a. Praiseworthiness requires that the agent act from appropriate concern for what is morally important (de re).

b. Moral rightness (de dicto) is not among the things that are morally important (de re).

For example, Nomy Arpaly defines praiseworthiness in the following way:

For an agent to be morally praiseworthy for doing the right thing is for her to have done the right thing for the relevant moral reasons - that is, the reasons for

\footnotetext{
${ }_{19}$ See (Arpaly, 2003; Arpaly \& Schroeder, 2013; Harman, 2011, 2015; Markovits, 2010; Smith (1994, 75); Weatherson, 2019).

${ }^{20}$ This denigration of concern for moral rightness de dicto can be traced back to the idea that it is 'fetishistic' (Smith, 1994, 75), or 'one thought too many' (Williams, 1981, 214).
} 
which she acts are identical to the reasons for which the action is right. [...]; and an agent is more praiseworthy, other things being equal, the deeper the moral concern that has led to her action [...]. Moral concern is to be understood as concern for what is in fact morally relevant [de re] and not as concern for what the agent takes to be morally relevant [de dicto]." $(2002,84$, fn. 7$){ }^{21}$

This definition is expressed in terms of praise- and blameworthiness for actions. Whether the agent is sufficiently concerned with what is morally important (de re) is what determines whether actions are praiseworthy. On Arpaly's view, only right actions can be praiseworthy. Since I am interested in the praiseworthiness of motivations rather than actions, my focus here is on my disagreement with De Re Concern views over which motivations are praiseworthy (that is, can generate praiseworthy action), rather than on our disagreements about which actions can be praiseworthy. ${ }^{22}$

In later work Arpaly and Timothy Schroeder connect praiseworthiness to intrinsic desires for what is morally right (de re). They say that:

"Good will is complete when it is instantiated by an intrinsic desire for the whole of the right and the good, correctly conceptualized" $(2013,202)$.

The correct conceptualization of the right and the good excludes conceptions that exclusively reference moral valence. As they put it, "agents who think of what they are doing under the concept MORAL [...] are not praiseworthy in acting" (2013, 177).

Relatedly, Elizabeth Harman emphasises the importance of concern for what is morally right (de re) for determining blameworthiness:

An action is blameworthy just in case the action resulted from the agent's caring inadequately about what is morally significant — where this is not a matter of de dicto caring about morality but de re caring about what is in fact morally significant $(2011,460)$.

In my view, De Re Concern views undersell the value of being motivated to do the right thing de dicto. One good thing about moral motivation de dicto is that it enables agents to avoid moral recklessness. Recognizing the praiseworthiness of moral motivation de dicto allows us to easily explain how avoiding moral recklessness could be praiseworthy - it stems from a praiseworthy motivation. De Re Concern views, on the other hand, are committed to the view that attempting to avoid moral recklessness is not praiseworthy. On these views, considering whether your moral beliefs are correct, and acting to mitigate the risk of wrongdoing is not something that is praiseworthy. So, if you do this, but end up getting it wrong, you deserve no moral credit - all

\footnotetext{
${ }^{21}$ In later work, Arpaly and Schroeder move towards talking about "intrinsic desire for the right or good (correctly conceptualized)", where the correct conceptualization of the right or good is never as moral rightness itself. As they explain, to act from this intrinsic desire is equivalent to acting for the right reasons (de re) $(2013,170)$.

${ }^{22}$ For some reasons to be suspicious of the idea that only right actions can be praiseworthy, see Hawthorne \& Srinivasan (2013).
} 
that matters is whether you were sufficiently concerned about what is in fact morally important. Moral rightness itself is not important, and so concern to do what is morally right cannot be praiseworthy. Proponents of De Re Concern views acknowledge this. For example, Elizabeth Harman argues that if one knows the non-moral facts of one's situation, it is blameworthy to act in ways that imply indifference to what is morally important. Furthermore, since having false moral beliefs is not exculpatory, the fact that you were trying to avoid moral recklessness cannot excuse any blame you might deserve for doing something wrong $(2015,57)$. Similarly, Brian Weatherson argues that being motivated to avoid moral recklessness would mean being motivated by an "unpleasant sort of motivation", by which he means motivation by rightness de dicto (2014, 141, 2019, Ch. 3).

De Re Concern views are thus unable to capture the praiseworthiness of attempts to do the right thing when these attempts go wrong, as in the Bad Advice Cases. The following section focuses on showing that De Re Concern views do indeed lack the resources to do this.

\section{Accommodating the cases}

This section discusses how De Re Concern views might attempt to accommodate the cases under discussion.

Julia Markovits $(2010,2012)$ offers one strategy for reconciling epistemic limitations with the commitments of De Re Concern views. On her view, actions are praiseworthy only when they are motivated by the moral right-making reasons (de re), and not when motivated by concern for what is morally right (de dicto). However, unlike the other De Re Concern views mentioned above, moral right-making reasons depend on what the agent ought, epistemically, to believe about her situation. She says: "we are morally required to do only what we have sufficient epistemic reason to believe it would be best to do, not what it would (in fact) be best to do" $(2012,291)$. This means that when someone you have reason to trust testifies that $\mathrm{X}$ is the morally right thing to do, you have a genuine moral reason to do $\mathrm{X}$, namely that "a reliable moral authority said that X is morally right". Since this gives you good evidence that $\mathrm{X}$ is the morally best thing to do, being motivated by it is praiseworthy. She says "if expert testimony gives us most reason to believe some act would be best then that testimony is the reason we ought to perform that act." $(2012,306)$ However, the reason you ought to do X, and the reason for which you would be praiseworthy for acting is not the de dicto reason "that $\mathrm{X}$ is morally right", but rather "that you have testimonial evidence that $\mathrm{X}$ is morally right". ${ }^{23}$

This approach might be thought to accommodate the praiseworthiness of agents like Jane without the need to disagree with the claim that being motivated by moral rightness de dicto is not praiseworthy. On this approach, Jane is praiseworthy not because she is motivated by moral rightness de dicto, but because she is motivated by

\footnotetext{
${ }^{23}$ In fact, Markovits' formulation of this point says that it is evidence about what is morally "best" rather than what is morally "right" $(2012,261)$. Though I am not convinced that this change in terminology helps her view avoid the objection I raise here, it is worth mentioning.
} 
her testimonial evidence that what she does is the right thing to do. However, even granting this reading, the most natural way to explain why she seeks out and follows this advice at all is that she cares about doing what is morally right. If we think she is praiseworthy for seeking out and acting on advice, and concern for moral rightness de dicto is what explains why she does this, it is somewhat puzzling why that concern could not also be praiseworthy. In other words, appeal to Jane's testimonial evidence does not completely remove the need for moral rightness de dicto in explaining her motivations.

It is perhaps worth noting the dialectical point that even if there were some way to accommodate the praiseworthiness of deferring to moral testimony while avoiding commitment to the praiseworthiness of motivation by moral rightness de dicto, this does not itself tell us that motivation by moral rightness de dicto is unpraiseworthy, and in so far as attempting to avoid commitment to the praiseworthiness of moral rightness de dicto requires philosophical effort, we should demand a very good argument that it is needed.

A second strategy De Re Concern views might employ would be to treat the epistemic limitations that cut agents off from what is morally important (de re) similarly to how they treat factual ignorance. Consider the following simple example of factual ignorance:

Blindness. Martin is blind. He is walking near a pond, and there is a child drowning in the pond. He does not see the child.

Martin's blindness prevents him from noticing a morally important feature of his situation: that there is a child drowning in the pond. Martin cannot care directly about the child drowning in the pond; he has no idea that there is a child drowning in the pond. ${ }^{24}$ However, it would be bad news for De Re Concern views if this was enough to make Martin blameworthy. To avoid this, they must show that Martin's failing to see the child in the pond is compatible with his having the right concerns.

For example, they might appeal to other relevant concerns that Martin has. Perhaps he cares generally about the welfare of children, and prefers that they not drown in ponds. Although he does not believe any are currently drowning, were he to learn that there was a child drowning in the pond, he would immediately be motivated to help. ${ }^{25}$ Perhaps this is a way to manifest appropriate concern also for this child. Or, perhaps it is that this particular child in the pond is not, in fact, one of the morally

\footnotetext{
${ }^{24}$ For example, some have thought that if one does not know that R, R cannot one's reason for acting, feeling, or anything else - see (Alvarez, 2010, 25; Hornsby, 2008, 251; Hyman 2015 (Ch. 6, 7), Neta, 2009, 690; Williamson, 2002, 64). In so far as caring about R involves being able to have R as one's reason, this has some plausibility. However, we should avoid understanding what it is to know R in a way that over-intellectualizes something's being one's reason. In fact, it is not just that Martin does not know the child is there, but that he is completely unaware of it. Dancy holds that one can act on the basis of considerations that one believes (even if they are false), but not that one can act on considerations one is completely unaware of (Dancy, 2000). See also Mantel (2018) for an account of acting for a reason that avoids over-intellectualization.

${ }^{25}$ Compare Weatherson's discussion of how practical irrationality can sometimes explain how an agent is blameless in virtue of having the right concerns despite not doing what those concerns demand (Weatherson, 2019, 89-91).
} 
important features of the world (de re). Perhaps these include only things at a higher level of abstraction: the welfare of children in general, the value of human life, maximising the good, and so on. So long as Martin cares about these, perhaps he has the right concerns after all. This would allow him to fail to notice factual details about the world - whether there are children in the pond — without this counting against his good will, provided he cares about other morally important things such as the welfare of children in general. It is worth noting that the appeal makes little sense without some reference to Martin's being blind. If he could see the child, then the fact that he cared in this more general way would not fully mitigate his failure to care about the child. On the contrary, it might suggest a blameworthy dislike of this child. This suggests that De Re Concern views are implicitly committed to an epistemic proviso: agents are blameworthy if they do not care sufficiently about things that are epistemically important, provided their epistemic situation includes no barrier to caring about these things. ${ }^{26}$

Can De Re Concern views use this parallel to absolve Jane of blame in the same way that they can absolve Martin of blame? In so far as neuroatypicality can also be seen as an epistemic barrier, we might think that they can. Indeed, the social experience of people on the autism spectrum is sometimes described as a kind of blindness-'mind-blindness' (Carruthers, 1996), or 'aspect-blindness' (Dinishak, 2019). Making use of this parallel would allow De Re Concern views to describe Jane as merely unaware of some facts of her situation, as Martin is. In so far as she cares in a general way about not upsetting other people, she is like Martin. Although she cares about what is morally important, her autism makes it difficult for her to work out exactly what that demands-like Martin, she lacks relevant empirical information (i.e. about which assertions are hurtful).

However, there are other respects in which Jane is not like Martin. While Martin would immediately care about the child drowning in the pond upon learning it was there, we cannot say the same of Jane with respect to the hurtful assertions that she does not realise are hurtful. Unlike Martin, her difficulties affect what she recognizes as important. We should all agree that not every case in which someone reports hurt feelings is serious moral transgression. Sometimes people are oversensitive, biased, or silly. Jane, correctly, does not think it is morally important to avoid hurting people's feelings in these "silly" cases. However, imperfect social understanding could make it hard to judge which are the "silly" cases of hurt feelings, and which are the non-silly, morally important cases. For example, perhaps she thinks that hurt feelings in response to revelations of personal information is silliness, or oversensitivity, and not morally important. In this instance, she is (let's suppose)mistaken about what is morally valuable, and so different from Martin, who merely lacks some of the facts. Jane wrongly thinks that some instances of privacy violation are cases of people being "silly" or oversensitive. She misunderstands the situation's moral features and their relative importance, not only its factual details. Here, Jane is comparable to me when I cook pasta: just as I lack appreciation for the value of adding salt to pasta, Jane lacks appreciation of some of the moral aspects of the situation that make some

\footnotetext{
${ }^{26}$ Indeed, Harman $(2015,60)$ mentions such an epistemic proviso when she includes the caveat that morally uncertain wrongdoers are blameworthy on the assumption that they "know" what their situation is.
} 
assertions wrong (i.e. that they are hurtful, or violations of privacy, or breaches of confidence). In comparison, Martin is more like someone who appreciates the value of salt but believes he is out of salt.

There is another respect in which we might think that Jane has the right concerns - she is sufficiently concerned about the impact of making hurtful assertions to seek advice. Assuming that something's being a hurtful assertion is morally important reason (de re) to avoid it, perhaps De Re Concern views can evaluate Jane as praiseworthy after all, because she follows advice that tells her to avoid the hurtful assertions. However, notice that Jane is only concerned to avoid hurtful assertions when this would be wrong. In many cases she does not care what makes those assertions wrong. Since trying to avoid doing the wrong thing de dicto is not praiseworthy according to De Re Concern views, this cannot help De Re Concern views accommodate the case, because Jane's primary motivation is to avoid wrongdoing (de dicto).

A third strategy available to De Re Concern Views is to deny the intuition that Jane is praiseworthy rather than blameworthy. Using Martin and the pond as an example, this would amount to agreeing that Martin does not care about this child in this pond, agreeing that the child in the pond is one of the morally important things worth caring about, and defending the view that he is blameworthy in virtue of failing to care about the right things. Of course, this would be implausible for Martin. Is it more plausible for Jane? Is her misvaluing of the morally important things that make some hurtful assertions wrong blameworthy, and irredeemable by any attempt to avoid moral risk?

I think we should resist this. Firstly, it embodies a failure to appreciate the full range of possibilities for the relationship between caring about what is morally important and quality of will. It relies on the following inference:

$\mathrm{S}$ fails to care about something that is morally important $\rightarrow \mathrm{S}$ has deficient quality of will.

In many cases, this inference is legitimate. However, in the clearest cases for which this inference is legitimate we would also be entitled to assume various further things that we are not entitled to assume about Jane. For example, that the agent could care more than they do, and that they do not face significant psychological or epistemic barriers to caring more. Consider an ordinary, neurotypical agent who asserts a hurtful truth such as "your new haircut looks bad". We can assume that she understands very well the hurtful effect this will have, and, unlike Jane, is in no way confused about why saying this to someone would have the hurtful effect. This makes it reasonable to assume that for this agent, this lack of concern indicates a negative (or insufficiently positive) attitude towards that person; it indicates deficient quality of will. However, things are different for Jane-she could not care more about the effects of asserting particular hurtful truths, because she does not fully understand these effects. This calls into question the legitimacy of the inference that Jane's quality of will is deficient. Furthermore, there are other apparently relevant aspects of the situation that Jane can and does care about - namely moral rightness de dicto, and avoiding moral recklessness. While caring about these things may not completely mitigate negative quality of will, when negative quality of will is absent, it is hard to see it as anything but positive. 
Given this, if it is possible to interpret Jane in such a way that she does not manifest deficient quality of will, we should do so. A commitment to inclusivity towards diverse perspectives demands that we err on the side of charitability when interpreting others' motivations. This is particularly true when there are negative consequences associated with interpreting motivations incorrectly. It is not nice to be found blameworthy, so we should not be overly eager to find blameworthiness where there is a chance we are mistaken. Sometimes, we may see behaviour that looks very much like blameworthy behaviour, and that would be blameworthy in a more ordinary case, but that on closer inspection is more ambiguous. In such cases, we should avoid interpreting the agent as ill-willed if there is another interpretation consistent with the information we have. To do otherwise would be to risk committing the injustice of filling in gaps in information with negative assumptions. To do this repeatedly would be to construct a systematically unjust model of moral evaluation, one that frequently makes negative assumptions of some atypical that are in fact underdetermined. While I am not suggesting that we change the criteria of blameworthiness purely to avoid unpalatable verdicts of blameworthiness, I am suggesting that we need to be more alert to when observed behaviour might underdetermine quality of will. We should avoid finding blameworthiness where there is merely difference, and we should be more imaginative in recognizing possible criteria of praise- and blameworthiness. Even if we agree with the De Re Concern views that when ordinary, fully informed, neurotypical people fail to care sufficiently about what is morally important (de re) they are blameworthy, we need not think that this holds generally. Features of the situation that count as blameworthy behaviour in neurotypical people do not necessarily also track blameworthiness in everyone. Neuroatypical people may well be in very different epistemic situations. We should be open to the idea that blameworthiness could look different given different psychological profiles. ${ }^{27}$

That said, we might wonder how far this goes. Some psychological barriers to caring about what is important do not seem to block the inference to negative quality of will. Indeed, they may sometimes explain it. For example, the psychological traits associated with psychopathy, narcissistic personality disorder, or extremely abusive upbringings might prevent agents from caring more than they do about what is morally important are well documented in the literature on moral responsibility. ${ }^{28}$ Like autism, we might view them as examples of neuroatypical differences. Should we also apply the principle of charity here and avoid blaming these agents because they are merely "different", as I have suggested we should for Jane? That depends. While we should apply the principle of charity, for these examples it is less clear that there is a way to interpret them such that they do not manifest negative quality of will - there are important differences between these cases and cases like autism.

For example, Jane's limitation in what she cares about is very specific - it stems directly from a lack of understanding of important aspects of the situation. She does not understand why people are upset when particular kinds of truths are asserted, and

\footnotetext{
${ }^{27}$ As a methodological point, we should also be careful to avoid relying only on (neurotypical) intuitions about blameworthiness in adjudicating this.

${ }^{28}$ See, for example, Greenspan (2016), Shoemaker (2011, 2015), Strawson (1962), Watson (1993), Wolf (1987), Vargas \& Nichols (2007).
} 
so she is not concerned to avoid asserting these particular kinds of hurtful truths. In contrast, psychopaths (as typically characterised by philosophers) fail to care about moral reasons in general, and typically do understand relevant right- and wrongmaking features underpinning the moral prohibitions. For example, consider someone who murders people for fun. There may be a psychological explanation of why he does this - perhaps he has a malfunctioning amygdala, or weak impulse control. Although these explanations would tell us why he has the desires and motivations he has-he enjoys killing people and lacks the willpower to not do so- they do not tell us about his epistemic situation and how he understands the world. In this respect these kinds of neurodiversity are distinct from neurodiversity that gives rise to the epistemic limitations I am focussed on here. We can usually not explain psychopathic agents' motivations by appealing to their epistemic situations, because they do not lack understanding in the way that Jane does. Nor are they, as usually described, concerned with doing the morally right thing de dicto. So, unlike for Jane, a benign interpretation of their motivations is less easy to find. ${ }^{29}$

That said, to the extent that any agent cares about avoiding recklessness, this could count towards a positive evaluation. Psychopathy or narcissistic personality disorder do not obviously pose psychological barriers to being motivated by de dicto concerns to avoid moral recklessness. Indeed, many philosophers have thought that psychopaths can be held morally responsible because they are able to recognise and understand legal and conventional prohibitions against acts like murder (see Vargas \& Nichols, 2007; Blair, 2007; Greenspan, 2016). This information could help them to understand when they are taking risks of wrongdoing. I argue elsewhere (Field, 2021), that acknowledging the moral significance of de dicto motivations to avoid moral recklessness provides a more nuanced and satisfying account of whether psychopaths, and other apparently ill-willed agents, are blameworthy.

In theorising about moral appraisal, we should be mindful of when a lack of concern indicates deficient quality of will, and when it merely indicates an epistemic limitation. Getting this wrong risks creating a system of blaming that fails to adequately accommodate neurodiversity. By always making the inference from failure to care to deficient quality of will, De Re Concern views place a good deal of weight on one feature of good moral character - concern for what in fact makes actions right or wrong. Of course, it is no bad thing to care about these things. However, if it is possible to act well without caring about these things, and if diverse psychological traits make it difficult for some agents to care in the right way about these things, then imposing this specific kind of moral concern as a condition of non-blameworthiness will not accurately capture who is genuinely blameworthy. It risks meting out blame, and withholding praise, in response to ways of thinking that do not manifest negative quality of will, but are merely atypical, non-ideal, or unusual.

Arpaly and Schroeder, who defend a De Re Concern view, attempt to accommodate neurodiversity without giving up the central moral importance of caring about what is morally important $d e$ re. They emphasise that many neuroatypicalities,

\footnotetext{
${ }^{29}$ I am not ruling out the possibility that they may deserve some other kind of excuse. The point is that as far as attributive blameworthiness goes, the same things do not seem true of them as are true of autistic agents such as Jane. For more comparisons between autism and psychopathy, see Field (2021).
} 
including autism, are compatible with sufficient concern for what is morally important (de re) $(2013,201)$. This is because, as they understand it, virtue (i.e. whether the agent cares sufficiently about what is morally important) is psychologically independent of various neuroatypicalities, including autism. ${ }^{30}$ While this is a worthwhile attempt, it is not clear that the psychological independence it relies on is plausible. Some psychological characteristics certainly appear to implicate what we care about. Consider depression. Diagnostic criteria for depression include "markedly diminished interest or pleasure in all, or almost all, activities" $(2013,160)$, and reports of "not caring anymore" (DSM-V 2013, 163). A default assumption is that this loss of concern could also extend to concern for the things that are morally important, whatever these are. If so, this would call into question the possibility of isolating what the agent cares about from wider features of her psychology. This leaves open the possibility that some psychological features, including the ones that we would not ordinarily think blameworthy, can corrupt one's concerns to the extent that, according to De Re Concern views, one is blameworthy. ${ }^{31}$ It thus also leaves open the possibility that neuroatypical agents can sometimes be more susceptible to blame in virtue of how they experience the world, if it is the case that the atypical ways they experience the world could prevent them from caring about what is morally important (de re).

A fourth way that proponents of De Re Concern views might interpret the Bad Advice Cases would be to agree that the agents are not blameworthy but hold that this is because they are exempt from ordinary moral evaluation. Perhaps their inability to care about what is morally important de re leaves them beyond the reach of ordinary moral evaluation. Perhaps, as some have thought, they are "marginal" agents (Shoemaker, 2015) to be engaged with from the "objective stance" (Strawson, 1962; Mason, 2015), to whom ordinary blame does not apply. This idea begins with Strawson. He contrasts the "ordinary" reactive attitudes that we have when blaming ordinary individuals, with the "objective attitude" that we might take towards individuals to whom ordinary reactive attitudes are inappropriate. Taking the objective attitude towards someone involves seeing that person as an object of "social policy", or "treatment". This attitude involves much more than merely offering advice on navigating difficult situations (as Jane's advisor does). It often means treating someone as a lessthan-full moral agent by bypassing their autonomy. This is sometimes an appropriate measure for children, or drunk people who are behaving inappropriately. It is sometimes necessary to steer such agents out of harm's way-removing sharp objects, or directing them away from potential conflict. This kind of management bypasses their autonomy - instead of giving them reasons against the unwanted behaviour, we simply prevent them from engaging in it. However, this approach is not an appropriate long-term strategy for dealing with other adults who have different concerns to us, due to differences in their ways of thinking. It is not appropriate because it does not treat them as full members of the moral community - in short, it is patronising.

\footnotetext{
${ }^{30}$ Concerns, for Arpaly and Scroeder, are intrinsic desires, and desires are identified by the causal role they play in the agent's psychological reward system. To intrinsically desire X is to treat X as a reward $(2013,127)$.

31 In fact, they do hold that psychological facts such as one's moral beliefs can corrupt concerns sufficiently to make one blameworthy $(2013,186)$.
} 
It is worth noting that part of the reason that this kind of management seems acceptable for children and drunk people is that we can usually be confident that their older, wiser, and more sober selves would agree that management was appropriate, and no longer identify with the motivations that led to the behaviour. Neurotypical people should not be at all confident that anything analogous would be true for highfunctioning autistic adults with whom they are involved morally or socially. Adopting the objective attitude of "management" inappropriately disregards the agent's perspective on the world, preventing them from participating autonomously in social practices. Not only this, but it is hubristic. It privileges a narrow range of perspectives and values in defining what the baseline criteria for membership of the moral community are. On the assumption that most people are neurotypical, this is likely to be somewhat biased.

This should be worrying for those who defend De Re Concern views. Fortunately, as I argue in the following section, there is a fairly painless way for these views to avoid the worrying implications, while preserving many, though not all, of their commitments.

\section{Inclusivity}

My proposal to accommodate the Bad Advice Cases is to expand the range of considerations that agents can deserve praise for responding appropriately to. Call this the Inclusive View. On the Inclusive View, it is good to care about what is morally important (de re), and it is also good to care about whether one is doing the right thing (de dicto). Praise is deserved for appropriate concern for either, or both. ${ }^{32}$ In the rest of this section I outline four reasons for accepting the Inclusive View.

First, as has been argued in the previous sections, the Inclusive View allows us to accommodate the praiseworthiness of agents who try to do the right thing de dicto, but act on bad advice. As the previous sections argued, the resources available to De Re Concern views do not allow them to accommodate these cases in plausible ways. By allowing concern for what is morally right de dicto to also, sometimes, be praiseworthy, the Inclusive View enables us to accommodate these cases.

Second, as discussed in Sect. 2, there are independent reasons to think that it is praiseworthy to care about whether one's action is morally right. We know that we are fallible and that we cannot completely rely on our own first-order judgments about what is morally important. In failing to care about whether we are correct in our first-order judgments, we are manifesting recklessness as to whether our actions are permissible. Caring about what is morally right de dicto is a way of caring about avoiding recklessness. Recklessness is recognised in many legal systems as a paradigm example of a blameworthy attitude-it is the mens rea of various crimes. In general, we should avoid taking unjustified risks of wrongdoing if we can help it. As

\footnotetext{
32 This is much weaker than the view that is sometimes charged with 'fetishism'. We can agree that it is good to care to some degree about moral rightness, without thinking that moral rightness is all we should care about.
} 
discussed, avoiding risk of wrongdoing seems to require de dicto motivation. ${ }^{33}$ The agents in the Bad Advice Cases know that if they do not defer to their advisors, they are highly likely to do something wrong - although they are in the dark about what that is. The Inclusive View correctly identifies deferring to advisors in these situations as praiseworthy, even though it is motivated by concern for moral rightness de dicto.

Third, the Inclusive View constitutes a fairly minor adjustment to De Re Concern views. It can agree with most of their verdicts about more ordinary cases, where the agent faces no epistemic barriers to caring about the right things. Expanding the set of morally important considerations to include considerations of moral rightness de dicto does not reduce the importance of caring about the right things (de re) when you can. Consider the following perfectly ordinary case of wrongdoing:

Scrooge. Scrooge is a wealthy businessman. He had a pleasant childhood and a good education. He does not care about the well-being of others at all-he cares only about his own interests. However, he cares very much about his profit margins. In the name of maximising profit he overworks and mistreats his employees, knowing that they suffer but caring very little about this.

In managing his business, Scrooge could care more about the welfare of his employees - he faces no particular epistemic or psychological barrier. Nevertheless, he does not care. De Re Concern views deliver the correct verdict here-he is blameworthy. However, they do so only because there is no particular barrier to his caring more about what is morally important. His failure to care thus suggests deficient quality of will. We can acknowledge this while denying that failure to care about first-order moral considerations is the only morally relevant factor in every situation. Furthermore, it is consistent with the Inclusive View that were Scrooge to care about doing the right thing, but not about any of the first-order considerations, he would be blameworthy - as De Re Concern views say he is. ${ }^{34}$ The key difference between Jane and Scrooge is that given these agents' particular psychology and epistemic circumstances, Jane's efforts are praiseworthy because she is responding appropriately to her epistemic situation, whereas Scrooge is not.

The Inclusive View can also agree with De Re Concern views on the evaluation of agents who act in moral ignorance. One much discussed example is Huck Finn.

Huck Finn:Frees a slave out of friendship and kindness, while believing this is a wrong act of stealing property.

Proponents of De Re Concern views have thought that Huck Finn is praiseworthy, because he does the right thing out of concern for the right reasons (friendship and kindness). The Inclusive View can agree with this. It can say that Huck Finn is praiseworthy because he cares about some of the important moral features of the situation, as we can expect him to. However, the praise must be somewhat muted. The Inclu-

\footnotetext{
${ }^{33}$ As previously mentioned, see Harman (2015), Weatherson (2014).

${ }^{34}$ Though evaluating whether this is true is beyond the scope of the paper.
} 
sive View cannot hold that he is maximally praiseworthy; because he takes a significant risk. As Sliwa (2016) notes, it would be even better, and he would be even more praiseworthy, if he also knew that what he was doing was right.

The Inclusive View can also agree with the broader conclusions that De Re Concern Views hold about morally ignorant agents who do wrong. While De Re Concern views hold that in so far as these agents are unresponsive to salient moral reasons, they are blameworthy, the Inclusive View adds an extra layer of considerations that these agents can be blameworthy for indifference towards, or praiseworthy for responding to. That is, considerations pertaining to whether they are doing something wrong. While it is often claimed that they are motivated to act rightly, it is not clear that this motivation is always sincere. Even when it is, we should expect someone sincerely concerned with doing the right thing to be reasonably cautious in managing their moral views. For example, we should expect them to avoid extreme views that would be disastrous if wrong and take seriously dissenting views. ${ }^{35} \mathrm{It}$ is not obvious that agents in the oft-discussed examples involving Nazi officials or Hittite slavetraders can be said to have been particularly cautious in this sense. This is particularly relevant when these agents occupy positions of power and influence, as Nazi officials or Hittite slave-traders did, the more power one has, the more harm one risks doing if one's moral views are incorrect. ${ }^{36}$

Finally, it is worth anticipating an objection. One might worry that including considerations of moral rightness among the things that it is praiseworthy to care about would inhibit moral progress by requiring agents to take seriously false moral views. Consider the following example from Amia Srinivasan: ${ }^{37}$

Domestic Violence. Radha lives in rural India. Her husband, Krishnan, regularly beats her. After the beatings, Krishnan often expresses regret for having had to beat her, but explains that it was Radha's fault for being insufficiently

\footnotetext{
35 This is not to say that someone could not be reasonably serious and still end up doing wrong. It is, however, worth noting how difficult serious moral inquiry can sometimes be, and that difficult moral inquiry may sometimes be demanded of us. For example, consider Rosen's "typical 1950s father" (Rosen, 2002, 63-4), who is considering whether to educate his daughters. According to the dominant moral views of his community, he ought not educate his daughters. He is also aware of alternative views according to which he ought to educate his daughters and it would be very morally wrong not to. However, as Rosen tells it, he finds these alternative views hard to understand. When he reflects on them, he encounters "a sensibility very different from his own, a sensibility that strikes him as wrong-headed" $(2002,67)$. As Rosen tells it, he has entirely ordinary capacities - the problem is just that he finds some false moral views 'obvious', when in fact they are false. However, finding something obvious is not a good guide to moral truthreflection on historical moral views tells us that, and we may well expect any serious and reflective moral inquirer to know that what they find obvious might well not be true. Verdicts of praise- and blameworthiness will depend on the details.

${ }^{36}$ One might wonder how to square this with the observation that moral progress often depends on moral views regarded at the time as "extreme". However, that a view is regarded as extreme does not mean that it is in fact extreme, or that it would constitute a significant moral risk. As I discuss elsewhere (Field 2019), reflection on the details of such cases usually reveals actions aimed at moral progress not to be reckless, because doing nothing would have been a greater moral risk.

${ }^{37}$ Srinivasan uses this case in the context of a dispute over whether epistemic justification is internalist or externalist. I leave the details of this debate aside. For the record, Srinivasan argues that this case gives us reason to think that epistemic justification is externalist rather than internalist, and so Radha's false belief is not justified.
} 
obedient or caring. Radha finds these beatings humiliating and guilt-inducing; she believes she has only herself to blame, and that she deserves to be beaten for her bad behaviour. After all, her parents, elders and friends agree that if she is being beaten it must be her fault, and no one she knows has ever offered a contrary opinion. Moreover, Radha has thoroughly reflected on the issue and concluded that, given the natural social roles of men and women, women deserve to be beaten by their husbands when they misbehave (Srinivasan $(2020,398)$ ).

One important worry for the Inclusive View is that it carries the unpalatable implication that it would be blameworthily reckless for agents like Radha to resist domestic violence, and praiseworthy for them to defer to their morally flawed communities out of concern to do the right thing (de dicto). This is an instance of a more general worry about taking moral uncertainty seriously_namely that if we must take false views about what is right seriously then this would inhibit moral progress. ${ }^{38}$ This would indeed be an uncomfortable result. Fortunately, the Inclusive View has resources to resist it.

First, it is worth pointing out that what the Inclusive View says is that some attempts to do the right thing, including those that take moral uncertainty seriously, are praiseworthy in some cases; not that taking moral risks is always blameworthy. Indeed, sometimes the right action might require a moral risk, but if it does, this risk would need to be justified. Not all risks are reckless, only unjustified risks. One way to determine whether an action would be justified is to weigh the costs and benefits of each option, given each candidate view. ${ }^{39}$ For example, consider two candidate views: the view that wives sometimes deserve to be beaten, and the view that domestic violence is always wrong. The first view says (perhaps) that beatings can sometimes improve marital relationships. It can help "wayward' or "disobedient" women become better wives, and therefore better people. Meanwhile, on the alternative view, where domestic violence is always wrong, domestic violence is a particularly horrible form of abuse - nothing good can come from it. If the first view is correct, and wives do sometimes deserve to be beaten, then the worst that happen if Radha resists is that she prevents some improvements to her own marriage (and perhaps those of other women whom she might inspire to resist). However, if the alternative view is true, and domestic violence is always wrong, then then by failing to resist Radha fails to prevent some instances of domestic violence, which are grave moral wrongs and much worse than the loss of putative benefits to marriages achieved by domestic

\footnotetext{
${ }^{38}$ One might also reasonably worry that the Inclusive View generates the additional implausible result that Krishnan is praiseworthy, because he is motivated by a desire to do what is right and would not act as he does were he to believe it was not the right thing to do. However, the Inclusive View implies nothing of the sort. As for other agents who do wrong out of a motivation to do what is morally right, being in the grip of a false moral view does not remove Krishnan's blameworthiness for ignoring the various considerations against beating his wife that, we assume, he faces no significant barrier to recognising. It is also not clear that he has been sufficiently concerned to avoid recklessness-we do not know how much he has reflected on the issues at hand, how many other points of view he has considered, or how his actions compare to possible alternatives.

${ }^{39}$ Of course, this method is a simplistic approach to determining which risks are reckless. It is nevertheless popular, and sufficient to illustrate the point that working out which risks are justified takes more than merely pointing out that there is a risk.
} 
violence (according to the rival view). This suggests that Radha would not, after all, be reckless to resist domestic violence - indeed, resistance would be the least reckless thing to do.

Whichever view is true, Radha maximises expected moral value by resisting domestic violence. ${ }^{40}$ Therefore, the view that moral recklessness is blameworthy does not have the unpalatable implication that resistance to false moral views is reckless. ${ }^{41}$

\section{Conclusion}

I have argued that it is sometimes praiseworthy to try to do the right thing (de dicto), regardless of whether one is successful in doing the right thing, and regardless of whether one also cares about the first-order moral considerations of the situation. I have shown how De Re Concern views fail to accommodate this successfully. Not only do they give an incorrect assessment of the cases under discussion, but this assessment is particularly unaccommodating towards neuroatypical agents, as well as others who are epistemically cut off from moral reality. I argued that the way to deal with this is to recognise that moral rightness de dicto is among the things it is morally important and praiseworthy act out of concern for.

Acknowledgements There are many people who deserve mention for their help in writing this paper. In particular, Joseph Bowen, Jessica Brown, Giada Fratantonio, Magnus and Boadicea Dger, Michael Field, John Hyman, Zoe Johnson King, Max Kiener, Stefano Lo Re, Heloise McKeown, Quentin Pharr, Elizabeth Polgreen, Justin Snedegar, Clotilde Torregrossa, and Brian Weatherson, as well as various other colleagues at the Univeristy of St Andrews, the University of Michigan, the Roots of Responsibility ERC project (Grant \#AH/T002638/1), and the Varieties of Risk AHRC project (Grant \#789270). Earlier versions of this paper were presented at the joint session of the Aristotelian Society, Brown University, and the National University of Singapore.

Open Access This article is licensed under a Creative Commons Attribution 4.0 International License, which permits use, sharing, adaptation, distribution and reproduction in any medium or format, as long as you give appropriate credit to the original author(s) and the source, provide a link to the Creative Commons licence, and indicate if changes were made. The images or other third party material in this article are included in the article's Creative Commons licence, unless indicated otherwise in a credit line to the material. If material is not included in the article's Creative Commons licence and your intended use is not permitted by statutory regulation or exceeds the permitted use, you will need to obtain permission

\footnotetext{
${ }^{40}$ We might add the caveat that this resistance should ideally be in some non-violent way, since violent forms of resistance would carry additional risks of wrongdoing.

41 We might also note, as Srinivasan does, that Radha's belief that she deserves to be beaten is false. The dominant ideology of her community is out of touch with moral reality, making it questionable whether it would be praiseworthy to take it seriously. As Srinivasan puts it, Radha's false belief as "not merely false, but moreover the product of a convincing, and systematic, patriarchal illusion: that it is men's place to subordinate women. This illusion - one that infects not only the testimony of Radha's peers and respected elders, but her moral emotions (shame, remorse) and best attempts at rational reflection-ensures that Radha has no dependable access to the moral facts of her situation. Radha, despite her own best efforts, is tragically cut off from moral reality" $(2020,399)$. If these false views do not at all rest on the moral facts of the situation, then it is far from clear that they are epistemically justified, or (more importantly) that it would be reckless to ignore them. It is entirely possible that someone in Radha's position would be rational to think that domestic violence was very wrong. Furthermore, while it may be reckless to ignore what you have genuine epistemic justification to believe, it is not reckless to ignore misleading and unfounded opinions.
} 
directly from the copyright holder. To view a copy of this licence, visit http://creativecommons.org/ licenses/by/4.0/.

\section{References}

Alvarez, M. (2010). Kinds of Reasons: An Essay in the Philosophy of Action. Oxford University Press

American Psychiatric Association (2013). Diagnostic and Statistical Manual of Mental Disorders (5th Ed.)

Anderson, E. (2015). "Moral Bias and Corrective Practices." Proceedings and Addresses of the American Philosophical Association 89: 21-47

Arpaly, N. (2003). Unprincipled Virtue: An Inquiry Into Moral Agency. Oxford University Press

Arpaly, N., and Schroeder, T. (2013). In Praise of Desire. Oxford University Press

Barnbaum, D. R. (2008). The Ethics of Autism: Among Them, but Not of Them. Indiana University Press

Baron-Cohen, S. (1999). Can Studies of Autism Teach Us About Consciousness of the Physical and the Mental? Philosophical Explorations, 2(3), 175-188

Baron-Cohen, S., Leslie, A. M., \& Frith, U. (1985). "Does the Autistic Child Have a 'Theory of Mind'?"Cognition21 (1)

Bell, J. (2018). “Depression Applied to Moral Imagination.”Southwest Philosophy Review34 (1)

Blair, R. J. (2007). "The Amygdala and Ventromedial Prefrontal Cortex in Morality and Psychopathy."Trends in Cognitive Sciences 11 (9)

Blair, R. J., Mitchell, D., \& Blair, K. (2005). The Psychopath: Emotion and the Brain. Blackwell Publishing Bloom, P. (2016). Against Empathy: The Case for Rational Compassion. Random House

Buss, S. (2014). "Experiments In Vivo, In Vitro, and In Cathedra." Ethics 124 (4)

Calhoun, C. (1989). "Responsibility and Reproach.” Ethics 99 (2)

Carruthers, P. (1996). "Autism as Mindblindness: An Elaboration and Partial Defence." In Theories of Theories of Mind, ed. Carruthers, P. and Smith, P. K.. Cambridge University Press

Coffield, F., Moseley, D., Hall, E., Ecclestone, K. (2004).Learning Styles and Pedagogy in Post-16 Learning: A Systematic and Critical Review. Learning Skills Research Centre

Dancy, J. (2000). Practical Reality. Oxford University Press

Dinishak, J. (2019). “Autism, Aspect-Perception, and Neurodiversity.” Philosophical Psychology 32 (6)

Dunn, R., Beaudry, J. S., and Klavas, A. (2002). Survey of Research on Learning Styles. California Journal of Science Education, 2(2), 75-98

Enoch, D. (2014). “A Defense of Moral Deference.” Journal of Philosophy 111 (5)

Fletcher, G. (2016). "Moral Testimony: Once More With Feeling.” In Oxford Studies in Metaethics: Volume 11, ed. Shafer-Landau, R. Oxford University Press

Field, C. (2019). Recklessness and Uncertainty: Jackson Cases and Merely Apparent Asymmetry. Journal of Moral Philosophy, 16(4), 391-413. https://doi.org/10.1163/17455243-20182687.

Field, C. (2021). Moral Appraisal for Everyone: Neurodiversity Epistemic Limitations and Responding to the Right Reasons. Ethical Theory and Moral Practice, 24(3), 733-752. https://doi.org/10.1007/ s10677-021-10212-5.

Frith, U. (1991). Autism: Explaining the Enigma. Blackwell Publishing

Frith, U., \& Happé, F. (1994). Autism: Beyond 'Theory of Mind.' Cognition, 50, 1-3

Grandin, T. and Panek, R.(2013). The Autistic Brain: Thinking across the Spectrum. Houghton Mifflin Harcourt

Greenspan, P. (2016). Responsible Psychopaths Revisited. The Journal of Ethics, 20(1), 265-278

Harman, E. (2011). "Does Moral Ignorance Exculpate?” Ratio 24 (4)

Harman, E. (2015). “The Irrelevance of Moral Uncertainty.” In Oxford Studies in Metaethics, Volume 10. Oxford University Press

Hills, A. (2009). "Moral Testimony and Moral Epistemology.” Ethics 120 (1)

Holroyd, J. (2012). "Responsibility for Implicit Bias.”Journal of Social Philosophy43 (3)

Hopkins, R. (2007). "What Is Wrong with Moral Testimony?"Philosophy and Phenomenological Research74 (3)

Hornsby, J. (2008). “A Disjunctivist Conception of Acting for Reasons.” In Disjunctivism: Perception, Action, Knowledge, ed. Haddock, A. and Macpherson, F. OUP 
Hurley, E. A. (2010). “Combat Trauma and the Moral Risks of Memory Manipulating Drugs.”Journal of Applied Philosophy27 (3)

Hyman, J. (2015). Action, Knowledge, and Will. Oxford University Press

Johnson-King, Z. A. (2019).“Praiseworthy Motivations.” Noûs,1-23

Kagan, S. (2011). "Do I Make a Difference?" Philosophy and Public Affairs 39 (2)

Kahneman, D., \& Slovic, P., and Amos Tversky (1982). Judgment Under Uncertainty: Heuristics and Biases (36 vol.). Cambridge University Press

Kauppinen, A. (2014). "Empathy, Emotion Regulation, and Moral Judgment." In Empathy and Morality, ed. Maibom, H.. Oxford University Press

Kinghorn, W. (2012). "Combat Trauma and Moral Fragmentation: A Theological Account of Moral Injury." Journal of the Society of Christian Ethics32 (2)

Le Guin, U. K. (1969). The Left Hand of Darkness. Penguin

Mantel, S. (2018). Determined By Reasons. Routledge

Markovits, J. (2010). “Acting for the Right Reasons.” Philosophical Review 119 (2)

Markovits, J. (2012). Saints heroes sages and villains. Philosophical Studies, 158(2), 289-311. https://doi. org/10.1007/s11098-012-9883-x.

Mason, E. (2015). "Moral Ignorance and Blameworthiness.”Philosophical Studies

McGrath, S. (2009). “The Puzzle of Pure Moral Deference.”Philosophical Perspectives23 (1)

Molendijk, T., Kramer, E. H., Verweij, D. (2018). "Moral Aspects of 'Moral Injury': Analyzing Conceptualizations on the Role of Morality in Military Trauma."Journal of Military Ethics 17 (1)

Murray, E. A. (2007). "The Amygdala, Reward and Emotion.” Trends in Cognitive Sciences 11 (11)

Nelkin, D. K. (2019). "Frontotemporal Dementia and the Reactive Attitudes: Two Roles for the Capacity to Care?" Journal of Applied Philosophy 36 (5)

Neta, R. (2009). "Treating Something as a Reason for Action.”Nô̂s43 (4)

Nickel, P. (2001). "Moral Testimony and Its Authority."Ethical Theory and Moral Practice4 (3)

Pashler, H., McDaniel, M., \& Rohrer, D. (2009). and Robert Bjork. "Learning Styles: Concepts and Evidence."Psychological Science in the Public Interest9 (3)

Prinz, J. J. (2006). “The Emotional Basis of Moral Judgments.”Philosophical Explorations9 (1)

Railton, P. (2014). “The Affective Dog and Its Rational Tale: Intuition and Attunement."Ethics124 (4)

Rosen, G. (2002). "Culpability and Ignorance.” Proceedings of the Aristotelian Society 103 (1)

Shoemaker, D. W. (2011). 'Psychopathy, Responsibility, and the Moral/Conventional Distinction', Southern Journal of Philosophy, 49(1):99-124. https://doi.org/10.1111/j.2041-6962.2011.00060.x

Shoemaker, D. (2015). Responsibility From the Margins. Oxford University Press

Silver, H. F., Richard, W., Strong, \& Matthew, J. P. (2000). So Each May Learn: Integrating Learning Styles and Multiple Intelligences. ERIC

Sinhababu, N. (2017). Humean Nature. Oxford University Press

Skarsaune, K. O. (2016). "Moral Deference and Authentic Interaction.” Journal of Philosophy 113 (7)

Slote, M. (1982). “Is Virtue Possible?” Analysis42 (2):70-76

Smith, M. (1994). The Moral Problem. Blackwell

Srinivasan, A. (2020). “Normative Externalism”. Philosophical Review129 (3):395-431

Stout, N. (2016). "Reasons-Responsiveness and Moral Responsibility: The Case of Autism."The Journal of Ethics 20 (4)

Strawson, P. F. (1962). "Freedom and Resentment.” Proceedings of the British Academy 48

Terroni, L. (2010). and Renerio Fraguas. "Depression Affecting Moral Judgment."Behavioral and Brain Sciences33 (4)

Toole, B. (2019). "From Standpoint Epistemology to Epistemic Oppression."Hypatia34 (4)

Vargas, M., \& Nichols, S. (2007). 'Psychopaths and moral knowledge', Philosophy, Psychiatry, and Psychology, 14(2):157-162

Watson, G. (1993). "Responsibility and the Limits of Evil: Variations on a Strawsonian Theme." In Perspectives on Moral Responsibility, edited by John Martin Fischer and Mark Ravizza. Cornell University Press

Weatherson, B. (2014). "Running Risks Morally.” Philosophical Studies 167 (1)

Weatherson, B. (2019). Normative Externalism. Oxford University Press

Williams, B. (1981). "Persons, Character, and Morality." In Moral Luck: Philosophical Papers 19731980, ed. Rachels, J. Cambridge University Press

Williams, B. (1995). Making Sense of Humanity. Cambridge University Press

Williamson, T. (2002). Knowledge and Its Limits. Oxford University Press 
Wolf, S. (1987). "Sanity and the Metaphysics of Responsibility." In Responsibility, Character, and the Emotions: New Essays in Moral Psychology, ed. Schoeman, F. D. . Cambridge University Press

Wolf, S. (1994). Freedom Within Reason. Oxford University Press

Zheng, R. (2016). "Attributability, Accountability, and Implicit Bias." In Implicit Bias and Philosophy,

Volume 2: Moral Responsibility, Structural Injustice, and Ethics, ed. Saul, J. and Brownstein, M..

Oxford University Press

Publisher's Note Springer Nature remains neutral with regard to jurisdictional claims in published maps and institutional affiliations. 